\title{
Editorial
}

\section{Bryology in India - Retrospect and Prospects}

\author{
Suresh Chandra Srivastava ${ }^{1}$, Dipjyoti Chakraborty ${ }^{2}$ and Afroz Alam ${ }^{2^{*}}$ \\ ${ }^{1}$ Former Head, Department of Botany, University of Lucknow, U. P. (India) \\ ${ }^{2}$ Department of Bioscience and Biotechnology, Banasthali University, Rajasthan (India)
}

Article history

Received: 21 September 2015

Accepted: 21 September 2015

Published online: 1 October 2015

(C) Srivatava et al. (2015)

Publisher

Horizon e-Publishing Group

Corresponding Author

Afroz Alam

$\square_{\text {afrozalamsafvi@gmail.com }}$

\begin{abstract}
Bryology in India has seen remarkable progress starting with Kashyaps' pioneering work, as reflected in its greatly improved multi-faceted research. This article summarizes some important developments in Indian bryology. Attention is drawn to the negligence of taxonomy in general and of the lower groups of plants in particular studies on bryophytes.
\end{abstract}

Keywords

Bryology; Bryophytes; Liverworts; Hornworts; Mosses

Srivastava, S. C., Chakraborty, D., and Alam, A. 2015. Bryology in India - Retrospect and Prospects. Plant Science Today 2(4): 123-125. http://dx.doi.org/10.14719/pst.2015.2.4.162
Bryology is the branch of plant science related with the methodical study of bryophytes (liverworts, hornworts and mosses). The detail study of the bryophytes started in the 18th century. "Reproduction of the ferns and mosses" is considered as the first ever documented research compiled by the German botanist Professor Johann Jacob Dillenius (1687-1747) in 1717. However, the credit for the establishment of bryology as a branch goes to the work of Johannes Hedwig, who elucidated the reproductive system of mosses in Fundamentum historiae naturalist muscorum (1792), and also gave a taxonomic account.

The initial areas of research in bryology include taxonomy and diversity analysis followed by ecological, economical, medicinal and ethnobotanical studies.

Globally, the principal centers of bryology research include Germany, Finland, USA, UK, Japan, Malaysia, Russia, China and India.

In India, Bryology was initiated by Professor Shiv Ram Kashyap (1882-1934), also known as 'Father of Indian Bryology'. Later on, bryologists like Profs. S K Pande and Ram Udar nurtured this branch of botany in India. Hence, there is a rich legacy of bryological studies in India. Since Kashyap, the study of bryology has strengthened, consequently several books and about thousands of research papers have been published on various aspects of bryology. Kashyap published the first ever paper on liverworts of western Himalayas in the year 1914. Later his work was published in two volumes: Liverworts of Western Himalayas and the Punjab plain, Part I in 1929 and Part II co-authored with R.S. Chopra in 1932, which includes valid illustrations and distribution of forms. In his first volume, 33 genera and 70 species are described, out of which six genera and 50 species were restricted to India. Kashyap recognized four well established genera new to the subject. These are Aitchinsoniella, Sauchia, Sewardiella and Stephansoniella. The genera were monotypic and endemic to India (Aitchinsoniella himalayensis, Sauchia, spongiosa, Sewardiella tuberifera, Stephensoniella bravipedunculata). Besides, he also described 39 new species. Of the forms described in his book, new species are Anthoceros erectus, A. chambensis, Notothylas indica, Riccia cruciata, $R$. melanospora, $R$. pathankotensis, $R$. robusta, $R$. sanguinea, Porella acutifolia, $P$. denticulata, $P$. obtusifolia, $P$. variabilis and in general species limited to India are Anthoceros erectus, A. himalayensis, A. chambensis, A. gollani, A. longii, Notothylas indica, $N$. levieri, Marchantia nepalensis, $M$ simlana, Riccia pathankotensis, $R$. himalayensis, $R$. melanospora, $R$. robusta, $R$. cruciata, $R$. sanguinea, etc. His theory of Retrogressive Evolution in Liverworts (Marchantiales) got distinctive position in the worldand is recognized as a significant contribution. According to this theory, simpler plants like Riccia are more evolved than organized plants such as mosses. 


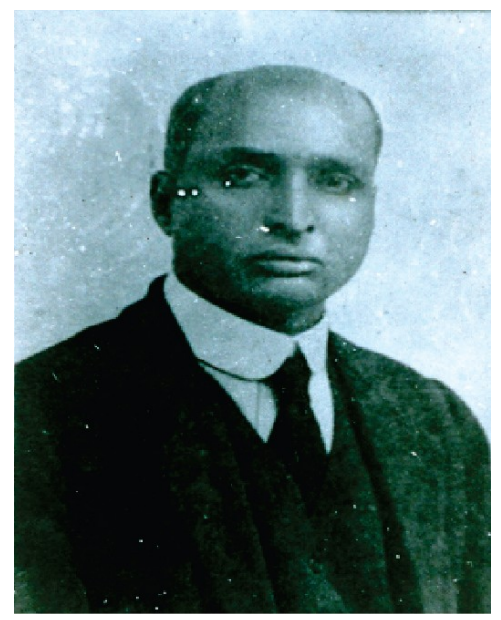

Prof. S. R. Kashyap (1882-1934)

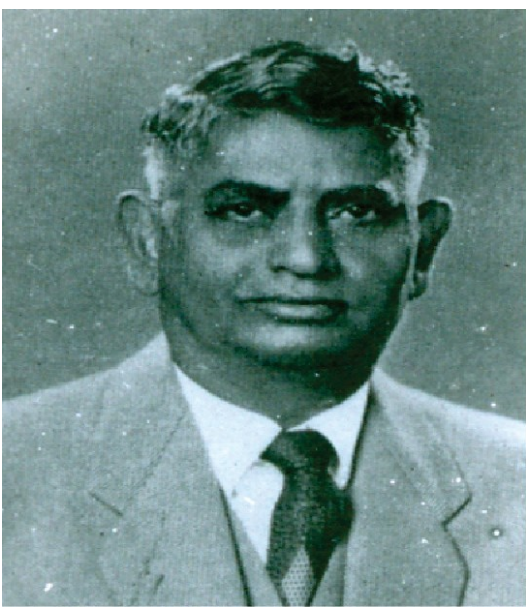

Prof. S. K. Pande (1899-1960)

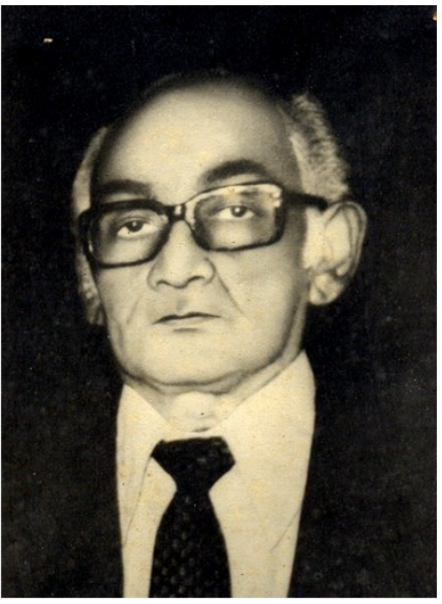

Prof. Ram Udar (1926-1985)
Prof. S. K. Pande, a noted student of Prof. Kashyap was the next gem from India in the field of bryology. His research interests included aspects on distribution, ecology, taxonomy, life cycle, ontogeny, cytology, phylogeny, etc. Amazingly amidst this apparent diversity in his study, a central theme always remained. He worked with zeal and put his best to assemble data on hepatic vegetation of India. He published 38 research papers individually or jointly in highly reputed journals. He published only one paper with Late Prof. Kashyap and described the life history of Aneura indica. His first two papers on life history of Riccia and Notothylas marked the beginning of his excellent contributions which gave him an enduring reputation as a bryologist. An unremitting problem since the time of Leitgeb on the origin of archesporium in Notothylas was perfectly concluded by him while working on $N$. levieri. He demonstrated that the archesporium is endothecial in origin and this he strongly held to emphasize the underlying similarity of the Anthocerotales with the rest of the hepatics. He suggested retaining Anthocerotales under Hepaticopsida. He established Nowellia indica (jointly with T.N. Srivastava), Riella vishwanathai (jointly with K.C. Misra and K.P. Srivastava), Cephalzia herzogiana (jointly with K.P. Srivastava), Riccia attenuata and $R$. aravalliensis (jointly with R. Udar) as new species. In his Presidential addresses to the Indian Botanical Society, he reviewed "Some aspects of Indian Hepaticology (Indian Botanical Society, 1958) and "The Anthocerotales, some aspects of their systematics and morphology" (Indian Science Congress, Botany Section, 1960). His important contributions are: Studies in Indian Liverworts: A Review (1936); Studies on Indian Metzgerineae I to III (1954, 55, 56); Studies in Indian Hepaticae I to IV (1942, 43, 49); Genus Riccia in Indian I to III $(1957,58,59)$; Bryology, Progress of Sciences in India (1957) etc. Writing a commemoration credential of Late Prof. Pande, Dr. Udar (1964) wrote "year after year since 1936 he undertook extensive plant collection trips in nearly all parts of the country till the end of his life every time bringing rich collections on which several valuable contributions were made by him. However, it is a great loss to bryology that he could not publish results of his study on most of these collections and his experience of a life time is thus so sadly not available." Udar who had more than 18 years of Prof. Pande's association as a student and colleague pursued his studies on bryophytes and established a new species of Notothylas, $N$. pandei to honor this great Indian bryologist.

Professor Ram Udar shared the same heritage of bryologists in India to which his mentor the late Professor S.K. Pande belonged. He published two books and over 200 research papers on varied aspects of Indian Hepaticology. His noteworthy contribution includes the discovery of the two orders: Calobryales and Buxbaumiales in the bryoflora of India, monographic studies on Indian Metzgeriaceae, Fossombroniaceae and Aneuraceae. Besides, he also worked on many members of Marchantiales and Jungermanniales, a group earlier not so well understood in India as it is today. His contributions on Indian Anthocerotae, particularly on the genus Notothylas are worth mentioning. He imparted training in research to a number of students of whom ten have received their Ph.D. degree under his able guidance. An ardent field botanist, Professor Udar led regular excursion trips to nearly all the parts of India and built up a very rich collection of liverworts along with his research associates. Most of his collections have been preserved in the Lucknow University Hepatic Herbarium (LWU) (Srivastava, 1986).

Professor Udar was a member of the American Bryological and Lichenological Society, British Bryological and Lichenological Society and Nordic Bryological and Lichenological Society, apart from being life member of the Indian Botanical Society and Palaeobotanical Society. The first ever association of bryologists in the form of Indian Byological Society was established by Prof. Udar for deliberations on issues related to the group and continues to be a vibrant forum till date. He played a crucial role in the 
functioning of the society as a Founder-President. He was crowned by being elected Fellow of the Indian National Science Academy in January 1985 - the highest achievement for a scientist in this country. He has left behind a well established school of bryology at Lucknow University which would continue to keep up the high traditions of bryological research in India so ably set by him. His legacy is thriving by excellent work in bryology by his able students, viz. Prof. S. C. Srivastava, Former Head, Department of Botany, University of Lucknow; Dr. D. K. Singh, Former Director In Charge, Botanical Survey of India, Kolkata; Dr. Virendra Nath, Former Emeritus Scientist, N.B.R.I., Lucknow; Dr. A. K. Asthana, Senior Scientist, N.B.R.I., Lucknow and Professor Geeta Asthana, Lucknow University to name a few.

Most of the contemporary active bryologists and bryological centers of India are associated to the above mentioned stalwarts in bryology. Initially, bryological research was more or less limited to the centers like Botanical Survey of India, Kolkata; National Botanical Research Institute, Lucknow; Bryology Unit, University of Lucknow which are renowned worldwide for their efforts in bryology. However, at present many more centers in states like Jammu \& Kashmir, South India, Odisha, Andhra Pradesh, Maharashtra, Gujarat and Rajasthan have joined the list. Studies in molecular bryology, genetics, drought tolerance, medicinal properties, ecology, economy and ethnobryology that require the application of modern, sophisticated tools and techniques are also being done in addition to the traditional taxonomical approach.

Numerous workers (Bhardwaj, Srivastava, Maheshwari, Kapil, etc.) were encouraged by Kashyap to work on various aspects of life cycle of these amphibian plants. The bryophytes of Pachmari have been described by Pande and Srivastava (1952), of Mount Abu by Bapna and Vyas (1962) and from the various parts of India by Udar, Gangulee, etc. Several new species, e.g., Riella vishwanathai (Pande et al., 1954), Calobryum indicum (Udar and Chandra, 1965), C. blumii (Udar et al. 1965), Haplomitrium hookeri (Udar and V. Chandra, 1962), etc. have been recorded from India. The discovery of Buxbaumia, from western Himalayas (Deoban, 10,500 feet above sea level) by Udar, Srivastava and Kumar (1965) is of tremendous importance. The plant shows similarities with $B$. minakatae. It is a unique bryophyte (moss) which has a conspicuous sporophyte with very small gametophyte. It is partially saprophytic leading to an unusual mode of nutrition among bryophytes. It is now referred to as a new species, $B$. himalayensis. Numerous species are being reported new to science, new to India and endemic regularly. At present Botanical Survey of India (Kolkata), National Botanical Research Institute (Lucknow), Bryology Laboratory, University of Lucknow are among the prominent and active centers of bryological research in India.

However, bryology originally considered as an essential component of study and research in plant science is now fighting for its survival because; in the era of Biotechnology it is considered outdated. As a result, now the Bryological studies are restricted to the undergraduate course only and at post graduate level many universities have dropped this group from their syllabi. The educationalists of our country need to pay adequate attention to this group and revive the research and also Despite worldwide increasing interest in bryology, in India very few students take Bryological research due to lack of job opportunities with bryology as their research specialization. Invariably, in most of the universities of India bryology is taught by a non-specialist. Molecular phylogeny, applied genomics, targeted mutagenesis, biochemistry and metabolism, unraveling the secrets of photosynthesis are relevant topics of biology research. Mosses show excellent attributes of model plant systems and are attractive experimental plants, an aspect which has largely been ignored by Indian Bryologists.

A concerted effort towards reviving bryology as a preferred discipline of study is required. The responsibility of reviving interest in these rejuvenating plants lies with contemporary experts and researchers in the field to restore it to its past glory.

\section{References}

Bapna, K. R. and G. G. Vyas. 1962. Studies in the liverworts of Mt. Abu (India). I. A preliminary account. J Hattori Bot Lab 25: 81-90.

Kashyap, S. R. 1929. Liverworts of western Himalayas and Panjab plains. Vol. 1, University of Panjab, Lahore. $129 \mathrm{Pp}$.

Kashyap, S. R., and R. N. Chopra. 1932. Liverworts of western Himalayas and Panjab plains. Vol. 2, University of Panjab, Lahore. $137 \mathrm{pp}$.

Pande, S. K. and K. P. Srivastava. 1952. The hepatic vegetation of Pachmarhi (Madhya Pradesh): A preliminary survey. J Indian Bot Soc 31: 342-351.

Pande, S. K., K. C. Mehta, and K. P. Srivastava. 1954. A new species of Riella Mont., R. vishwanathai Pande, Misra et Srivastava sp. nov. Rev Bryol Lichenol 23:165-172.

Srivastava, S. C. 1986. Professor Ram Udar (1926-1985). Cryptogam Bryol Lichenol 7: 499-509.

Udar, R. and V. Chandra. 1965. A new species of Calobryum Nees, C. indicum Udar et Chandra from Darjeeling, Eastern Himalayas, India. Rev Bryol Lichénol 33: 555.

Udar, R. and V. Chandra. 1965. On two new species of Mannia, $M$. foreaui Udar et Chandra and $M$. personii Udar et Chandra with a note on the genus on the genus and its India species. Can J Bot 43: 147-160.

Udar, R., S. C. Srivastava, and D. Kumar. 1971. A new species of Buxbaumia Hedwig, B. himalayensis Udar, Srivastava et Kumar, from Deoban Western Himalayas, India. Trans Brit Bryol Soc 6: 266-269.

Udar, R., V. Chandra, and S. Chandra. 1965. Calobryum blumii Nees-A taxon new to Indian Flora. Curr Sci 37:265. 